\title{
Paradoxical Malignant Embolism, Brief Review
}

\author{
George M. Weisz ${ }^{1 *}$, Richard Haber ${ }^{2}$ \\ ${ }^{1}$ University of New England, and New South Wales. Sydney. Australia. \\ ${ }^{2}$ University of Notre Dame, Sydney.
}

*Corresponding Author: George M. Weisz, University of New England, and New South Wales. Sydney. Australia.

Received date: December 07, 2021; Accepted date: December 20, 2021; Published date: January 04, 2022

Citation: George M. Weisz, Richard Haber (2022) Paradoxical Malignant Embolism, Brief Review J, Clinical Case Reports and Studies 3(2); DOI: $10.31579 / 2690-8808 / 100$

Copyright: () 2022, George M. Weisz, This is an open access article distributed under the Creative Commons Attribution License, which permits unrestricted use, distribution, and reproduction in any medium, provided the original work is properly cited.

\begin{abstract}
:
During gestation period the oxygenated maternal blood is transferred to the embryo via the placenta and umbilical cord into the right atrium. It is further transferred through an interatrial shunt to the left atrium, the Foramen Ovale, and distributed to the embryonic body. The foramen is closed after the birth, but remains occasionally patent, permitting embolization through a right to left shunt. This is transferring thrombi, fat, cement and bony spikes, air, and occasionally malignant tissue. This brief review is on the malignant embolization.
\end{abstract}

Key words: embolism; paradoxical palignant tissue

\section{Introduction:}

The topic of Paradoxical embolism, namely embolization through a Patent Foramen Ovale (PFO) has preoccupied the authors, considered an important clinical condition, with an interesting pathogenesis. The authors reviewed the published cases of blood clot embolization and cases following orthopedic procedures, all ending in the cerebrum $[1,2]$.

\section{The historical background}

takes us back centuries: The inter-atrial foramen was apparently known since Galen's time in the second century CE and was discussed in more detail in Italian medical publications in the $16^{\text {th }}$ century. It was known as "trou de Botal" in the French medical literature of the $19^{\text {th }}$ Century. Thrombosis was described in 1842 by Virchow, the great pathologist in
Berlin, whereas the clinical syndrome of embolism was described by $\mathrm{H}$. Wallman in 1859. The well-known clinical pathologist Julius Cohnheim in Berlin /Leipzig in 1872 defined the clinical aspect of embolism through the foramen ovale. It was further developed by Wilhelm Zhan in 1881 as "consequential embolism". Amadee Rostand in Geneva in 1884 called it "Embolie croisee" and finalised a year later, again by Wilhelm Zahn as "Paradoxical embolism", the title that has remained permanent ever since [3-6].

The condition during the subsequent century advanced in a prophylactic and curative way, but with limited success[7]. At present the diagnosis is based on saphenous and tibial vein ultrasound testing, with Transoesophageal Echocardiogram identification of the cardiac anomaly and bubble inflation to prove pathology [1].

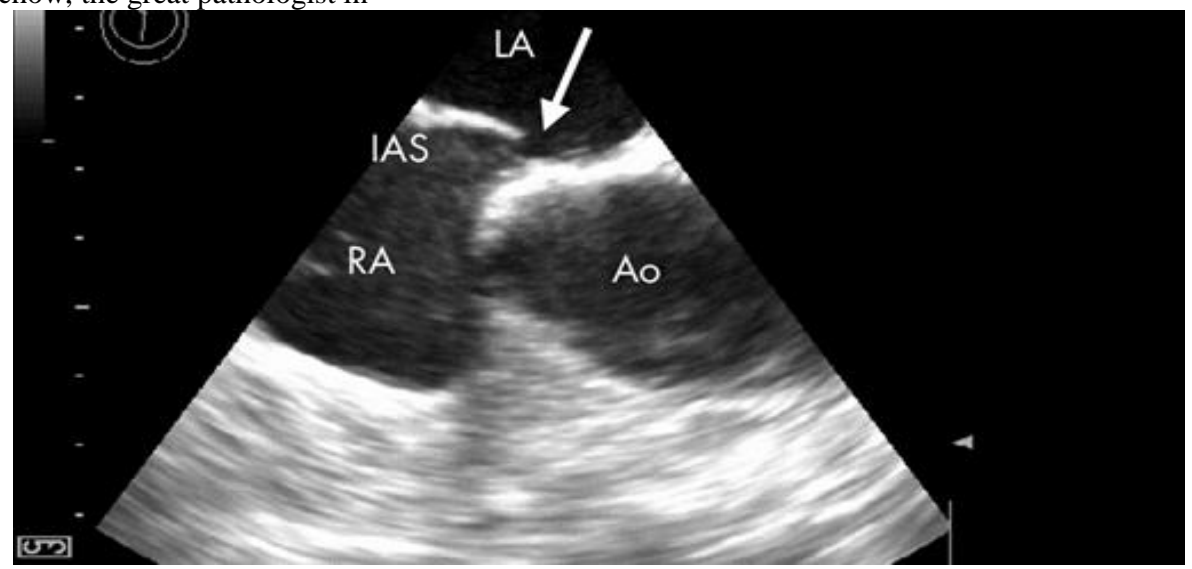


Once diagnosed, in the presence of cerebral symptoms, the curative treatment is thrombolysis (unless contraindicated), insertion of intra-cava filter. Identification of cranial circulation with CT angiogram would also allow for a therapeutic embolectomy.

In a recent case, we described a cerebral embolism after a long-haul transAtlantic flight, with venous thrombosis in both calves [1].

\section{Findings, the Incidence in the literature}

Whilst the incidence of PFO was documented as persistent between 25$35 \%$ of the population, a review (NCBI/Google Scholar) found documented spread of malignant tissue only in 15 publications out of the total of 300 reviewed articles on cerebral infarct due to malignant tissue [8-23]. It is therefore likely that many cases were not diagnosed, the PFO unknown and unsuspected found incidentally in indirect investigations, (transesophageal ultrasound or CT angiograms) or in autopsy.

Our results were as follows, published cases of paradoxical malignant embolization.

\begin{tabular}{|l|l|l|l|}
\hline No. & Author & Publication & Tumor location \\
\hline 1 & Thompson & 1929 & Testicular \\
\hline 2 & Wolfe & 1960 & Argentaffinoma \\
\hline 3 & Wood & 1992 & Wil's tumor \\
\hline 4 & Mitsui & 2001 & Ovarian \\
\hline 5 & Dumont & 2002 & Renal \\
\hline 6 & Horowitz & 2002 & Pharynx \\
\hline 7 & Wada & 2007 & Ovarian \\
\hline 8 & Schallner & 2011 & Renal \\
\hline 9 & Uga & 2012 & Breast \\
\hline 10 & Thibault & 2018 & Breast \\
\hline 11 & Portigari & 2019 & Ovarian \\
\hline 12 & Kamakura & 2019 & Bladder \\
\hline 13 & Yasui & 2020 & Renal \\
\hline 14 & Yu & 2020 & Breast \\
\hline 15 & Wagner & 2021 & Lung \\
\hline
\end{tabular}

Table 1.

\section{The pathogenesis:}

The oxygen and nutrient requirement of the embryo is supplied via placenta and umbilical arteries and veins, bypassing the inactive lung tissue. Postpartum the lungs are expanding, taking over the respiration and the inter-atrial connection (Foramen) is closed, except for about 25\% of the population. It remains usually asymptomatic, unknown, discovered during unrelated investigations. Should the Foramen remain open, a sudden increase of right sided cardiac pressure, would result in a shunt toward the lesser pressure gradient of the left cardiac side, allowing for embolization. This was the mechanism of embolization from a lung disease presented in an extensive essay of two mechanisms of pathogenesis of malignant embolism [3-6].The suggested mechanisms of paradoxical embolization in the literature were:

a. The pulmonary tissue with either primary or secondary lung malignancy, allows the spread of cancer cells via capillaries to the left atrium and then into the arterial system.

b. In the presence of PFO, malignant tissue originating from various origins, suspended in the right atrium is shunted into the left side of the cardiac system. The authors' suggestion would be a rather combined mechanism, i.e a transfer mechanism of malignant tissue from the lungs, via a cor pulmonale, increasing the right atrial pressure, and secondarily leading through the shunt to the left atrium via an opened Foramen Ovale.[3].

\section{Final Comments}

A review of paradoxical tumor embolization in the literature, was expected to lead to a significant incidence. The small figure of the published incidence would not permit any conclusion, but to:

1. Raise attention to the likelihood of missed diagnoses within the high percentage of PFO in the population and promote the study of the extent of passage of malignant cells through foramen ovale.

2. Raise the question for the need to close an asymptomatic PFO, a dispute in the literature that reached no definite conclusion.

The authors support the closure of existent PFO in a patient diagnosed with malignancy. This intervention could reduce the chance of early spread of tumor cells into the arterial system, rather than be stagnant, at least temporarily in the pulmonary filter.

\section{References:}

1. Weisz GM, Haber R.: (2021) Cerebral Infarct in a Long-Haul Traveler, From a Deep Vein Thrombosis, an unusual presentation, In a Person with Patent Forman Ovale. A Special Case of Paradoxical Embolism. Arch. Health Sci. 5(1):1-6.

2. Weisz GM, Haber R: (2021) Paradoxical Embolism in Orthopedic patients. A brief- review.EC Orthopaedics. 12 (11):52-6.

3. Rigatelli G, et al: (1951) Patent foramen ovale as a preferential mechanism for increasing likelihood of brain tumour metastasis. Am. J. Cardiovasc. Dis.2012: 2(1):29-33. Johnson BI: Paradoxical Embolism. J Clin. Path;4:16-21.

4. Cohnheim J F: (1877) Thrombose und Embolie. Vorlesungen fur Algemeine Pathology. vol 1.;134 
5. Benaroyo L: (1991) Contribution of Friedrich Wilhelm Zahn: Google Scholar

6. Rostan Amadee (1884) Contribution a l'etude de L'EMBOLIE CROISSE:Geneve. Rivera \& Dubois

7. 7. Levin-Epstein R, Kumar P, et al: (2021) Investigation of patent foramen ovale as a mechanism for brain metastasis in patients with prior lung involvement Clin.\& Trans.Ocol. 23:783-7.

8. Thompson T, Evans W: (1929) Paradoxical Embolism. Q J Med; 23:135-150

9. Wolfe HRI, Davies A, et al: (1960) Metastatic Argentaffinoma Secreting 5-Hydroxytryptamine in a Patient with a Patent Foramen Ovale. Br Med J. (5177): 925-929.

10. Mitsui T, Aoki Y: (2001) Patent Foramen Ovale complicated by Paradoxical Embolsim and Brain Infact in a Patient with Advanced Ovarian Cancer. Gynec.Oncol. 83(3): 608-9.

11. Dumont E. Racine N. et al: (2002) Paradoxical cerebral emboli of hypernephroma metastatic to the right ventricle five years after primary tumor resection. 123: 572-573.

12. Horowitz MB, Carrau R, Crammond D, Kanal E: (2002) Risks of Tumor Embolization in the Presence of an Unrecognized Patent Foramen Ovale: Case Report . American Journal of Neuroradiology (6) 982984;

13. Wada Y, Yanagihara et al: (2007) Paradoxical Cerebral Embolism. J Stroke \& Cerebrovasc. Dis. 123(3):572-3.

14. Gonzalez MA, Hiovani M etal: (2010) Cerebral Infarcts and growing cerebral metastasis traced to an unusual source: Paradoxical embolism of renal cell carcinoma. Am J Case Rep 11:163-165.
15. Thibault LVM'Wiseman D et al: (2018) Pulmonary Micro-tumor emboli resulting in paradoxical emboli. Pulmon. Circul. 8(2):1-5

16. Schallner N. Wittan, et al.(2011) Intraoperative Pulmonary Tumor Embolism from Renal Cell Carcinoma and a Patent Foramen Ovale Detected by Transesophageal Echocardiography .J.Cardiothor\& Vasc. Anesth25 (1):145-7.

17. Uga S, Ikeda S et al: (2012) An autopsy case of acute cor pulmonale and paradoxical systemic embolism due to tumor cell microemboli in a patient with breast cancer. Br.J. Case reports Dx doi.org 101136.

18. Kamakura M, Oakazaki A et al: (2019) Concomitant Pulmonary and Cerebral Tumor Embolism and Intracardiac Metastasis from Bladder Cancer. Clin Med Res. 17(3-4): 97-101

19. Yu H, Deng H, et al: (2020) Paradoxical embolism after surgery for breast cancer: a case report.BMS Surg. 20 (148): 94

20. Gritsch, A. Abdallah, A. et al: (2020) Acute ischemic stroke as a result of paradoxical embolus in a patient with renal cell carcinoma, intravenous tumor thrombus extension, and patent foramen ovale. Neurology.

21. Yasui T, Okuda Y et al: (2020) Acute myocardial infraction caused by tumor embolus originating from upper tract urothelial carcinoma .Cardio-oncol; 6:18-25.

22. Wagner BJ, Hobbach HP et al: Cardiac Metastasis causes paradoxical embolism. Cancer Reports 15.7.2021 doi.org/10.1002/cnr2.1513.

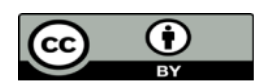

This work is licensed under Creative Commons Attribution 4.0 License

To Submit Your Article Click Here: Submit Manuscript

DOI: $10.31579 / 2690-8808 / 100$
Ready to submit your research? Choose Auctores and benefit from:

$>$ fast, convenient online submission

$>$ rigorous peer review by experienced research in your field

$>$ rapid publication on acceptance

$>$ authors retain copyrights

$>$ unique DOI for all articles

$>$ immediate, unrestricted online access

At Auctores, research is always in progress.

Learn more https://auctoresonline.org/journals/journal-of-clinical-case-reportsand-studies 